\title{
A Sufficiently Just Liberal Society is an Illusion
}

\author{
Lea Ypi ${ }^{1}$ \\ Published online: 30 September 2019 \\ () The Author(s) 2019
}

\begin{abstract}
Matteo Bonotti's book on Partisanship and Public Reason in Diverse Societies is grounded on a theory of partisanship that sees the demands of public reason as internal to the very definition of a party. Bonotti suggests that partisanship is not only compatible with but essential to the stability and legitimacy of a well-ordered liberal society. My paper aims to raise some questions internal to the liberal account of partisanship so as to probe the methodological foundations and plausibility of the liberal framework taken as a whole. My argument is that the assumption of a sufficiently just liberal society on which the book grounds its defence of partisanship makes us ill-equipped to face some of the most critical challenges that liberal societies face in the world that we live.
\end{abstract}

Keywords Political liberalism · Public reason · Partisanship · John Rawls

\section{Public Reason and Intermediary Associations}

Partisanship and Political Liberalism in Diverse Societies is a distinctive and welcome contribution to the growing literature on the normative relevance of political parties (and partisanship) for contemporary democratic theory and practice. Firmly situated in the liberal paradigm, Matteo Bonotti develops a new analysis of partisanship seen through the lens of John Rawls's defence of public reason and the justificatory role it plays in Rawls's theory of political legitimacy. Taking its cues from Rawls's sparse (but sympathetic) remarks on the role of political parties, the book explores a relatively neglected aspect of the institutional architecture necessary to guarantee the effective functioning of public reason. Grounded on a theory of partisanship that sees the demands of public reason as internal to the very definition of a party, Bonotti suggests that partisanship is not only compatible with but essential to the stability and legitimacy of a well-ordered liberal society.

Lea Ypi

1.1.ypi@1se.ac.uk

1 London School of Economics and Political Science, London, UK 
In what follows, I shall examine these aspects in turn. My aim is to raise some questions internal to the liberal account of partisanship so as to probe the methodological foundations and plausibility of the liberal framework taken as a whole. It is also to illustrate the consequences that an analysis of partisanship embedded in a statist theory of liberal political obligation has for theories of civil disobedience and revolutionary action in the service of global justice. The core argument is that the assumption of a sufficiently just liberal society on which the book's defence of partisanship is grounded makes us ill-equipped to respond to some of the most critical challenges that liberal societies face in the contemporary world.

According to Bonotti, what makes the case of partisanship especially interesting from the point of view of political liberalism is the relation of mutual reinforcement between the demands of public reason and the normative ideal of partisanship. Retrieving a political and theoretical tradition that emphasises partisanship in its ideal form, Bonotti emphasises that, unlike other partial associations, parties at their best promote the good of the whole political community rather than that of particular parts of it. Parties differ from other self-interested agents in society, such as factions and interest groups, because the principles and aims to which they are committed are publicly articulated in a way that is constrained by a civic (non-particularist) conception of the good.

The non-reductionism of public reason to partial conceptions of the good is also central to the ideal of justification pursued in Rawls's political liberalism and at the heart of Bonotti's main argument. As Rawls puts it, public reason spells out an ideal of political justification in light of which citizens of a well-ordered society confront each other in the public sphere by appealing to arguments that have only political value and that bracket particular conceptions of the good. The justification of the coercive use of power requires that citizens (understood as free and equal persons) obey only those laws and policies that they can freely endorse. But they can only freely endorse those laws and policies that are accessible to them on the basis of 'higher-order interests associated with their moral powers' (p. 74) and without presupposing commitment to any particular comprehensive doctrines.

Bonotti's view is that parties are best understood as intermediary associations whose demands are situated between civil society and the state. Like other groups in civil society, they are voluntary and emerge from a plurality of interests and principles to which they bring coherence and visibility. But like other institutions of the state, they translate such interests and principles into political platforms, electoral proposals and eventually government policies and laws. Such laws and policies are coercively imposed on the rest of the citizenry and therefore require public justification in terms that everyone can share.

The exploration of this intimate connection between partisanship and public reason, leads Bonotti to reject an 'extrinsic' view of public reason according to which the latter constrains partisanship to the point of suffocating it. As some critics would have it, public reason asks partisans to suppress comprehensive doctrines in the name of a more general political good which is formulated independently from the contribution of partisans (p. 63). This interpretation, Bonotti, rightly emphasises, if it were true, would have important implications for a number of questions central to the development of democratic reason-giving in a liberal democracy: the site of 
justification, the issues that are subject to debate, the type of constraints compatible with such requirements and so on. But to properly understand the relationship between partisanship and political liberalism, one needs to move beyond the extrinsic view, interpret partisanship in ideal terms, and understand that there is a virtuous connection between partisanship and public reason.

To see why public reason does not extrinsically constrain partisanship but is enabled by it, we need to reflect on the intermediary nature of political parties as associations grounded both in civil society and in the state. It is precisely in virtue of their intermediary nature, Bonotti argues, that parties are in the best position to articulate their demands as demands of public reason and to promote the overlapping consent that is necessary to the legitimacy and stability of a liberal society. The link between partisanship and public reason is, he suggests, an intrinsic one. Indeed, as Bonotti nicely puts it, when citizens choose to engage in party politics, when they promote their demands as partisans 'they are already committing to public reason and to an overlapping consensus' (p. 109). On this account, although comprehensive doctrines inform the platforms of many (perhaps most) political parties, partisanship processes play an essential role in illustrating how they relate to widely shared political principles. Moreover, parties have a duty to 'present and justify their claims on the basis of reasons that all citizens could accept' (p. 100). Is this interpretation justified?

\section{The Ideal and Reality of Partisanship in Liberal Societies}

The intrinsic link between partisanship and political liberalism is persuasive only if one shares a number of assumptions on which Bonotti's interpretation of both relies. At various points in the book, the author emphasises that the ideal of partisanship embraced throughout is restricted to liberal societies, that parties (as we know them) may well fall short of such an ideal of partisanship, and that the distinction between a party and an interest group makes sense given a particular normative conception of what a party is. To defend that normative conception, Bonotti relies on two arguments: one historical and the other philosophical. Historically, he draws on a broadly liberal tradition and on authors as diverse as Edmund Burke, Robert von Mohl, Johan Kaspar Bluntchli and Hans Kelsen, all of whom argued that parties are crucial to the emergence and consolidation of public authority out of a plurality of interests and views. From a philosophical perspective, he shares with recent normative treatments of partisanship, an idealised understanding of parties as dynamic associations that articulate particular principles and aims in a way that can also meet demanding standards of political justification. Without such demanding standards, he argues, partisan politics would not be legitimate, it would amount to a coercive imposition of laws and rules shared by one subset of the citizenry over others. The idealised interpretation of partisanship here overlaps exactly with the idealised interpretation of Rawlsian public reason. Indeed, as Rawls puts it, public reason demands that when we justify state rules we should only appeal to those reasons that citizens, as free and equal persons, could accept given their common interests, that is the 'higher-order interests associated with their moral powers' (p. 105, citing Rawls). 
But in assessing the plausibility of this argument it would be useful to know more about the relation between ideals and reality both with regard to liberalism and to partisanship. What kind of liberalism is at stake here? To what extent does partisanship so conceived mirror the reality of existing parliamentary liberal democracies? Is Rawls's political liberalism a better version of historical liberalism or a mere ideal to which the latter aspires but which has never actually been realised?

On this point, both Bonotti's answer and Rawls's are ambiguous. The implications of the ambiguity for the liberal project of reconciliation of partisanship with public reason are just as telling in Bonotti's case as they are in Rawls's. If we interpret both partisanship and political liberalism as ideal projects, they are of course compatible but as a matter of definition, because we specify each in such a way that they can only be compatible. In other words, both are constrained by particular moral standards determined, in Rawls's formulation above, by 'higher-order interests' associated with 'the moral powers' of 'free and equal persons'. Partisanship and public reason mutually sustain each other in virtue of their relationship to (and articulation through) practices of reason-giving that specify the normative standards of political legitimacy. We take public reason to provide the standard of political justification on the basis of which the exercise of political power is legitimate according to some specified criterion of generality and reciprocity, and we single out as appropriate to the emergence and shaping of public reason only those agents that comply with such standards, i.e. political parties under a certain normative interpretation of the practice of partisanship.

On the idealised interpretation, partisanship and public reason are compatible because they relate in the same way to a particular, democratic, ideal of political legitimacy. But there is very little in the empirical (or historical) relation between them to suggest that partisanship and public reason actually are (or have ever been) consistently embedded in a particular institutional regime type (liberalism) in this way. For some critics, this will be fatal. Why should we be interested in a theory of partisanship so abstract and removed from contemporary political circumstances that it has nothing to say about the troubling nature of particular partisan phenomena that not only fail to promote but actively undermine public reason (e.g. the recent rise of right-wing populist politics) ? $^{1}$

If we take seriously the idealised interpretation, the interesting conclusion is not that the normative conception of partisanship and public reason are compatible: this is a mere implication of our definition of each of them. The interesting conclusion is how they offer different yet related articulations of the standard of political legitimacy to which a democratic society must aspire. Such an idealised interpretation is plausible and attractive not because it shows how partisanship and public reason are compatible but because it frees both from the institutional constraints of (existing) political liberalism whilst retaining their relation to democratic theory. To put it differently, the point at which partisanship and public reason become compatible is also the point at which both require us to give up political liberalism as a historical

\footnotetext{
1 See for a reply to this point also Jonathan White and Lea Ypi, 'In defence of political parties: a reply to critics', Political Studies Review, vol. 16, issue 4 (2018), pp. 303-305.
} 
political project and move to a radical democratic reinterpretation of the values that inspire it.

\section{Power, Interests and the Illusion of the 'Reasonably Just' in Existing Liberal Societies}

Needless to say, the democratic interpretation is my favourite account of the relationship between partisanship and public reason. ${ }^{2}$ I suspect Bonotti would not agree with this reading, and for obvious reasons. His project is neither to criticise political liberalism nor to advocate a conception of partisanship that can help overcome its limitations. His argument is premised not on the criticism of liberal societies but on the assumption that they are, as he puts it, 'reasonably just' (p. 12 and elsewhere). It is only because of this assumption that the consent to join a political party and respect its internal rules and norms also entails consent for the political institutions within which that party operates and a more general acknowledgement of the obligation to obey the laws (p. 13). But I have doubts on whether any existing liberal society actually meets the demanding standards of justice that Rawls puts forward such that it can qualify as even 'reasonably just'. Part of my hesitation comes from a pessimistic interpretation of the predicament of existing liberal societies where the constitutional subordination of political power to the economic interests of propertyowning elites means that any interpretation of public reason carries with it an inevitable economic bias. It is this economic bias that undermines equality of political power and that existing political parties, as well as the party system as presently conceived, struggle to rectify.

There are many passages in Rawls, as well as many interpretations of his project, that share quite a few of these worries. One of the most prominent examples is Rawls's argument that the most adequate regime types to realise his ideal of justice as fairness are either liberal socialism or property-owning democracy, but not welfare state capitalism. ${ }^{3}$ Even more relevant to our case is that Rawls's arguments against the capitalist welfare state are premised on the importance of the fair value of political liberties which, he argues, is undermined when particular groups of citizens are allowed to accumulate wealth and power to shape public policies against the common good. ${ }^{4}$ In terms of the normative understanding of partisanship, the implication of the argument is that under conditions of private ownership of the means of production most existing political parties represent de facto factions. They

\footnotetext{
2 See for more discussion, Jonathan White and Lea Ypi, The Meaning of Partisanship (Oxford: Oxford University Press 2016), ch. 3 on political justification.

3 See John Rawls, Justice as Fairness: A Restatement, ed. by Erin Kelly (Cambridge, MA: Harvard University Press 2001), p. 139.

4 For two recent book-length discussions of Rawls's work that emphasise this point see for example Alan Thomas, Republic of Equals: Predistribution and Property-Owning Democracy (Oxford: Oxford University Press, 2017) and William Edmundson, John Rawls: Reticent Socialist (Cambridge: Cambridge University Press, 2017). See also my discussion in 'The Politics of Reticent Socialism', The Catalyst, vol. 2 , issue 3 (2018), pp. 157-176.
} 
are identical to interests groups who can petition the government to obtain private favours and advance their own particular good at the expense of the rest of society. ${ }^{5}$

Given this diagnosis, it is difficult to see what would make existing liberal societies even 'reasonably just' as Bonotti's book emphasises. Either we dismiss the close relationship between Political Liberalism and A Theory of Justice altogether or we have to come up with an analysis of partisanship that is detached from the historical limitations of liberalism and directed to its critical scrutiny. If Rawls's arguments against welfare state capitalism are as strong as they are, there simply are no examples of contemporary liberal democracies that meet the demanding standards of his theory. Indeed, the constitutional essentials of existing liberal democracies all protect a particular conception of property which entrenches social and political inequalities that in turn undermine the fair value of political liberties. It is therefore plausible to argue that Rawls's political liberalism is grounded on a particular conception of practical reason, and cannot be associated to any political order that does not serve the higher order interests linked to the moral powers of free and equal persons. ${ }^{6}$ But such political orders are not already out there; they must be created.

\section{Political Liberalism and Overlapping Consensus}

I am not sure to what extent Bonotti's assessment of the reality of liberal democracy is compatible with the idealised, democratic version of the relation between partisanship and public reason that I have just outlined. Since both Rawls's and Bonotti's reading are often ambiguous on this point, more clarity would be welcome. Bonotti's analysis of partisanship often reads as if the connection between partisanship and public reason were not just a matter of democratic aspiration but a historical given; note his emphasis that an analysis of partisanship as irreducible to factionalism 'has deep historical roots' (p. 101). Indeed, part of the challenge of his book consists in showing how partisanship is essential to the legitimacy of a liberal society in virtue of its contribution to the construction of an overlapping consensus from the plurality of comprehensive political and religious doctrines that characterise it. As Bonotti explicitly argues, what is at stake in his reconciliation between partisanship and public reason is not a 'moral' but a 'political' conception of the common good (p. 106). In other words, it is a conception of the common good rooted in what Rawls calls the public political culture of a particular society, and characterising broadly shared values and principles such as freedom and equality (p. 106).

Yet such a reading of the relation between public reason and partisanship, where the norms of public reason are inevitably seen as embedded in the constitutional apparatus of existing liberal democracies, collapses the distinction between the

\footnotetext{
${ }^{5}$ For a discussion of how this concern with material inequality has been invoked (often with good reason) to reduce an ideal of partisanship to the reality of factionalism, see White and Ypi, Meaning of Partisanship, ch. 2.

${ }^{6}$ For an interpretation of political liberalism that emphasises its distance from conventionalist, historicist, and relativistic interpretations, see Rainer Forst, "Political Liberalism: A Kantian View", Ethics 128, no. 3 (2017): 123-44.
} 
normative ideal and the empirical practice of partisanship with which Bonotti's account begins. In other words, if political parties are taken to develop the standards of public reason from which they are then in turn constrained, it is hard to see how public reason would then act as the standard on the basis of which it is possible to distinguish between desirable and undesirable forms of partisanship, as required by Bonotti's initial normative understanding of partisanship. But if, on the other hand, the standard of criticism is given by the extent to which norms of public reason comply with a moralised view of justification and a conception of the person as free and equal, how can this view rest on the reality of the public political culture of particular liberal democracies and to what extent is it a merely 'political' conception of public reason?

It would be difficult for Bonotti to drop the claim to a distinctively 'political' interpretation of Rawls's public reason since that is precisely what enables him to defend an 'intrinsic' rather than 'extrinsic' account of it in relation to partisanship. The former, recall, is an account where the demands of public reason are developed from within partisan practices whose contribution is to turn views that originate from the comprehensive doctrines of particular groups into proposals that all citizens can share in principle. Such an analysis is crucial to question interpretations of Rawls that suggest how the standards of overlapping consensus are too demanding when it comes to members of groups with comprehensive philosophical views. As Bonotti argues, criticising Bryan McGraw's analysis of religious political parties in nineteenth-century Europe, if we appreciate the value of partisanship in its intrinsic relation to political liberalism, we will see that McGraw's account suffers from an unduly restricted, empirical view of partisanship, which fails to take into account the normative rationale and benefits of the practice. As Bonotti explains, in the transition from a modus vivendi developed around compliance with constitutional essentials to one where parties engage with each other by formulating proposals that are justified in accordance with certain standards of public reason, parties display a commitment to a political conception of justice that proves their intrinsic link to political liberalism.

Here again, Bonotti invokes Rawls when he argues that 'once a constitutional consensus is in place, political parties must enter the public forum of political discussion and appeal to other groups who do not share their comprehensive doctrine. This makes it rational for them to move out of the narrower circle of their own views and to develop political conceptions in terms of which they can explain and justify their preferred policies to the wider public so as to put together a majority. As they do this, they are led to a political conception of justice' (p. 108, citing Rawls).

Notice, that Rawls's analysis, here and elsewhere, is purely instrumental. Unless parties are able to phrase their concerns as concerns that could be shared by others, Rawls argues, they would not be able to form a majority and win elections. Indeed, 'to gain enough support to win public office', Rawls argues, parties cannot act 'like interests groups who petition the government on their behalf', parties must 'advance some conception of the common good'. ${ }^{7}$ Bonotti acknowledges the limitations of Rawls's

\footnotetext{
7 See John Rawls, A Theory of Justice (Cambridge, MA: Harvard University Press), p. 195.
} 
argument at this point but emphasises that the instrumental account of partisanship could be complemented with a normative theory that highlights not only how parties work in practice but how they ought to be. He is right, of course, on this point: the instrumental conception is not only normatively insufficient but also empirically dubious. There are plenty of cases in which parties can win elections by sheer recourse to corruption, manipulation, ideological deception, support by a minority of powerful lobbyists or business elites - indeed this may well be how they come to power most of the time. The question is whether this is justified. If we are committed to freedom and equality, it should be clear that it is not.

Yet this seems to open a gulf between Rawls's account of partisanship and Bonotti's. Rawls's argument for partisanship is at best underdeveloped and at worst misguided: the problem is not whether parties can win elections and form governments without some conception of the common good, but what implications the latter has for the political legitimacy and stability of a well-ordered society. Bonotti's argument in favour of the normative conception of partisanship does much more than Rawls in illustrating the desirability of the practice. Indeed, if there is a fault here, it is that Bonotti understates the extent of his contribution to the debate on public reason by making it sound like an implication or further development of Rawls's view. The project is much more ambitious than that.

Had Bonotti been more critical of Rawls in developing his own account of partisanship, we might have been able to obtain a better grasp of the reasons for which Rawls hesitated in his endorsement of the normative value of partisanship. But as things stand, this reader is left with the feeling that precisely because Bonotti's project is not entirely reducible to Rawls, his own response does not really save Rawls from McGraw's objections about the limits of public reason in making place for the contribution of political groups characterised by their commitment to comprehensive doctrines. McGraw's criticism of Rawls may well be unduly empirical. But so is Rawls's own view of partisanship. We can readily grant Bonotti that this is insufficient in both cases. But as far as McGraw's specific target goes, since his aim is to explain how really existing partisans engage with really existing public reason (as opposed to how they would engage if both categories and practices were redefined), the tensions he highlights are genuine and problematic. If we take partisans as they are, Rawlsian public reason in its idealised version would clearly provide an external constraint on their activity so the extrinsic reason of partisanship has force. If we take them as they should be, then the objection becomes weaker and we have an intrinsic account. But this is only because Bonotti gives us a more sophisticated reading of partisanship, which is not the same as that advanced by Rawls. Either way the argument would benefit from more clarity on the implications of more or less idealised accounts of partisanship for the stability of liberal democracies taken as they are.

\section{Partisanship and Political Obligations}

In addition to the question of stability, another important component of Bonotti's overall argument in the book is the contribution that partisanship makes to the legitimacy of political liberalism. The argument here is developed in relation to debates 
on political obligation. Bonotti begins by clarifying that his aim is not to establish which account of political obligation is plausible, nor is it to defend the view that citizens in general have any political obligations. Instead, he argues that there are special political obligations that apply to partisans as members of distinctive political associations, and that they do so in virtue of two features. The first is positional obligations, i.e. the positional obligations partisans endorse as occupants of particular social roles and positions (in this case within political parties or partisan structures) and that come with accepting the responsibilities of that role. The other argument concerns the political obligations that partisans have as a result of the privileges and benefits that they enjoy from participation in politics at different levels.

I will examine these arguments in turn. Let me first, however, begin by expressing some scepticism about the idea that it is possible to defend the special political obligations of partisans whilst being generally agnostic on whether there are any political obligations of citizens in general. Bonotti's argument is that we can be agnostic on the latter since if citizens have no general political obligations, then partisan obligations are the only obligations partisans have. If there are such obligations, then these obligations would be additional political obligations to obey the law.

But what would it mean for partisans to have political obligations in a context in which citizens in general lack an obligation to obey the law? Take some of the cases that Bonotti mentions as examples of positional duties of partisans: the duty not to take bribes, the duty to represent all constituents, the duty to respect party laws and regulations around elections, the duty of loyal opposition, duties to respect the procedures of gaining office and engaging with one's adversaries as prescribed by the legal doctrine of particular states. Surely, these duties only make sense in a context in which there is a general acknowledgment of the responsibilities of citizenship and of the main social and political institutions through which political life is regulated. Otherwise, to whom would the obligations of partisanship be actually addressed?

To see this point, imagine a society in which citizens do not acknowledge their duty to obey the law. In such a society, citizens would not recognise the authority of parliament as the site where legitimate decisions and policies that structure their lives are made. In a context such as this it would be meaningless to say that MPs have nevertheless a duty to represent constituents. That duty is premised on constituents' recognition of MPs as their legitimate representatives, which is in turn premised on the recognition of parliament as the institutional body in which representatives make laws, which is in turn premised on the recognition of the authority of laws. I think it is a mistake to say that we can set aside the question of whether citizens have general political obligations suggesting, as Bonotti does, that 'regardless of whether citizens of liberal democracies have any political obligations, partisanship generates specific and sui generis political obligations' (p. 6). What he should have said instead, is that we should grant that there are some political obligations that apply to all citizens, but we can remain agnostic on the source of these obligations, or on the best theory able to justify them, or on how substantive such obligations must be.

Bonotti might respond to this objection by turning to the first argument in favour of the obligations of partisans: their positional obligations. In one of the most insightful and innovative parts of the book, he discusses the moral force of partisan 
obligations in relation to their voluntary decision to join a political party. As Bonotti suggests, "the "internal" consent to join a political party entails "external" consent to the laws of the polity' and therefore generates a consent-based moral duty to obey those laws (p. 13). Such a perspective on political obligation is taken to be immune to the standard objections to consent-based views of political obligation more generally, for example how to interpret the ambiguity around tacit or explicit consent or how to explain the voluntary nature of political associations. There are of course still uncertainties - the rigidity of party membership, the plurality of meanings of partisan membership in different countries, how to understand different expressions of partisan loyalty, and so on. Yet my main concern with this argument is one that Bonotti does not tackle, and that maps onto the larger question that I have been trying to raise in this paper: the idealised assumption of sufficiently just liberal societies in which Bonotti's theory of partisanship is inscribed.

The point can be introduced as follows. If we assume that partisan obligations justify more general political obligations to obey the laws of a liberal society, what scope is there for civil disobedience? And can there be a revolutionary party under such circumstances? Bonotti would argue here that since the background assumption is one where the society in question is sufficiently just, neither the question of civil disobedience, nor the demand to fundamentally change the system are pertinent ones. But my concern here is that the assumption of sufficient justice does much more work than it is entitled to given the political nature of the questions that the book raises. By assuming a sufficiently just society, the book renders us incapable of reflecting on some of the most urgent challenges that liberal societies face as they seek to justify their basic political set-up to the rest of the world. If we assume that liberal societies are basically fine as they are, why do we even have the problem of justifying their laws? Either those who think that the laws are purely coercive and cannot be democratically justified are evil or deluded or ideologically manipulated or they have a point. If they are deluded or morally wrong, surely their objections can be discounted as outside the scope of reasonable disagreement. But if they have a point, their primary motivation for joining a particular party may be precisely to fight for a kind of radical, constitutional change that is incompatible with declaring allegiance to the laws of the political community in which they operate. Here I think it is important to detach the procedural question of how one engages with one's political adversaries (i.e. respecting the idea of regulated rivalry that is at the heart of partisanship) from the substantive assumption of a threshold of justice with regard to which a liberal society can be justified.

The difficulty with Bonotti's argument as it stands is that in linking the obligations of partisanship to the problem of political obligation more generally, it obstructs rather than enables us to answer some of the most interesting real-world questions around the ethics of activism. Those are cases where far from justifying obeying the laws, partisanship requires breaking them. Take for example the case of the 'Stansted 15', the group of activists who were recently convicted of terrorrelated offences for using peaceful means to stop a chartered flight with migrants who were being deported to Nigeria, Sierra Leone and Ghana as part of the UK 
government 'hostile environment policy'. ${ }^{8}$ Suppose I am a partisan that finds the deportation of migrants as currently practised by the UK Home Office deeply problematic. The practice is fully legal and, what is more, the justification for its legality results from the assumption that a liberal society is entitled to control its borders such that all those who are perceived as violating territorial integrity can be punished and repatriated. Yet, a cosmopolitan egalitarian activist may take a different view of the constitution. They may think that unless the state is transformed in a cosmopolitan egalitarian direction, its laws remain deeply problematic. In this case being a partisan not only invites but requires actions of civil disobedience like those of the Stansted 15. It requires not obeying the law, but breaking it. But here we may ask: does the UK Home Office count as an institution of a 'sufficiently just' liberal society by the lights of Bonotti's theory? If the answer is yes, the morality of the theory is dubious. If it is no, its relevance is unclear.

The example of the Stansted 15 is instructive also for reflecting on another argument Bonotti makes to explain the relationship between the obligations of partisans as they relate to more general political obligations: the benefits view. In liberal democracies, Bonotti argues, partisans enjoy particular benefits that may not be available to ordinary citizens: they have a say in electing public officials, nominating candidates, and debating policies, often they are also the recipients of special state funding and subsidies that support their partisan activities. While such benefits may be more or less substantive depending on the level of one's involvement in a partisan association, they are usually important elements of a scheme of social cooperation where the general compliance with its rules ensures its ongoing functioning. For Bonotti, partisan cooperation can therefore be subsumed under a 'fair play' theory of political obligation, where the voluntary acceptance of the benefits of partisanship brings out the justification for distinctively political obligations to other partisans, including partisans of rival political associations.

However, there are reasons to be sceptical of the view that inter-partisan reciprocal political obligations are mostly due to their acceptance of the benefits of political association. While some of these benefits are undoubtedly important and sufficiently connected to functioning state institutions, Bonotti does not say much about the burdens of political association and the impact such burdens might have on our duty to engage with other partisans, including their content and scope. In other words, it seems to me that the argument from fair play only applies to those partisans who take the constitutional framework of the society in which they operate as a given, and who therefore are unable to radically question the scope, content and addresses of their political obligations. But this seems to assume what we are trying to prove: that the general context of application of certain political obligations confers associative benefits that partisans would not otherwise have. From the point of view of partisans who may see the political context in which they operate as constricting rather than enabling, such benefits could also be considered burdens.

To see this point, consider again the case of cosmopolitan egalitarian activists. While it is true that the state does give them funding and opportunities for the public

\footnotetext{
${ }^{8}$ https://www.theguardian.com/uk-news/2018/dec/10/activists-convicted-of-terror-offence-for-blockingstansted-deportation-flight.
} 
exercise of their activities, it also prevents them from forming alliances with other partisans in other parts of the world, running for joint elections with them, coming up with a shared political platform and so on. This does not mean that they can realise whatever they are committed to in the state in which they operate, at least not without radically changing the state. Of course, it also does not mean that they can treat their adversaries however they like because there are no state-based constraints they recognise as authoritative. They may still acknowledge some obligations of reciprocity to other partisans, such as not trying to destroy or eliminate them, and they may still seek to engage with them in the public sphere in a relatively respectful way. But the reasons behind such obligations may be instrumental or morally justified in light of their own principled commitments, not justified with reference to the benefits generated by the political context in which they operate.

For the benefits of partisanship to count as benefits rather than burdens, we rely on the assumption of the justification of the political context in which partisans operate, in other words, the normative standing of the liberal state and the obligations of citizenship that come with it. But that seems to presuppose what we are trying to justify. This seems to undermine one of the most important reasons one might have for being a partisan in the first place: to advocate for radical change in how the institutions of the liberal state operate with regard to their addressees, justification and scope.

\section{Conclusion}

I am not sure how radically Bonotti would disagree with the remarks I have made. As I tried to show throughout this paper, many misgivings would be removed with more clarity on how much work the assumption of a 'sufficiently just' liberal society does in his account, and on how one is to draw the line between a more or less idealised interpretation of the relationship between partisanship and public reason. Bonotti's defence of partisanship represents an admirable and unique effort to link the liberal analysis of public reason to the sites and practices of political justification through which ordinary citizens are mobilised and participate in shaping and transforming the political life. Yet a liberal interpretation of public reason rooted in a historicist, conventionalist or positivist understanding of legal and political norms undermines the radical scope of that transformation.

A sufficiently just liberal society is an illusion. The world in which we live has nothing to do with it. The earlier we abandon the illusion, the more effective our attempts to change it will be.

Open Access This article is distributed under the terms of the Creative Commons Attribution 4.0 International License (http://creativecommons.org/licenses/by/4.0/), which permits unrestricted use, distribution, and reproduction in any medium, provided you give appropriate credit to the original author(s) and the source, provide a link to the Creative Commons license, and indicate if changes were made.

Publisher's Note Springer Nature remains neutral with regard to jurisdictional claims in published maps and institutional affiliations. 